"This is a post-peer-review, pre-copyedit version of an article published in Argumentation. The final authenticated version is available online at: http://dx.doi.org/10.1007/s10503-0189465-y".

\title{
A Normative Pragmatic Theory of Exhorting
}

\begin{abstract}
We submit a normative pragmatic theory of exhorting — an account of conceptually necessary and potentially efficacious components of a coherent strategy for securing a sympathetic hearing for efforts to urge and inspire addressees to act on high-minded principles. Based on a Gricean analysis of utterance-meaning, we argue that the concept of exhorting comprises making statements openly urging addressees to perform some high-minded, principled course of action; openly intending to inspire addressees to act on the principles; and intending that addressees' recognition of the intentions to urge and inspire creates reasons for addressees to grant a sympathetic hearing to what the speaker has to say. We show that the theory accounts for the design of Abraham Lincoln's Cooper Union address. By doing so we add to the inventory of reasons why social actors make arguments, continue a line of research showing the relationship of arguing to master speech acts, and show that making arguments can be an effective strategy for inspiring principled action.
\end{abstract}

Keywords: exhorting, normative pragmatic theory, Grice, speech act theory, Lincoln's Cooper Union address

\section{Introduction}

Exhorting — urging and inspiring addressees to act on high-minded principles, duties, commitments, and the like—is widespread, occurring for example in sermons, interpersonal relationships, staff meetings, and civic discourse. Social actors occasionally encounter challenges and problems demanding extraordinary, unwelcome exertion, and need another social actor to urge and inspire them to live up to and fulfill obligations imposed on them by their fundamental commitments (Krause 2002, 11-12, 108-109). The capacity of exhortation to bring reasongiving discourse to bear on urging and inspiring principled action renders this speech act deserving of attention from students of argumentation. 
In rhetorical studies, Edwin Black has outlined a foundational account of exhorting: "the evocation of an emotional response in the audience induces belief in the situation to which the emotion is appropriate. In this genre, a strong emotional experience does not follow the acceptance of a belief, or accompany it; it precedes it. Emotion can be said to produce the belief, instead of the reverse" $(1965,138)$. One scholar has recently argued that Black did not go far enough - that speakers can effectively exhort even without generating "a formal belief" due to a neuropsychological mechanism of "emotional contagion," or "the auditor unconsciously begin[ning] to embody and likewise internalize the orator's emotional state” (Marinelli 2016, 471). Both accounts feature audiences' emotions, but on face a message designed to induce a wholly emotional or neurophysiological experience may be easily dismissed as manipulative, especially by addressees disinclined to disturb their cognitive equilibrium with attention to an exhorter's urgings. How can a speaker design an exhortation that influences even reluctant addressees to grant a sympathetic hearing to what the speaker has to say, and why can she expect it to work?

We answer this question by providing a normative pragmatic account of exhorting (e.g., van Eemeren et al. 2014, 454-459; Goodwin 2011; Innocenti and Kathol 2018; Jacobs 2000; Kauffeld 1998; Kauffeld 2009a; Kauffeld 2009b; Pinto 2007). After outlining basic normative pragmatic theory, we first argue that exhorting comprises making statements openly urging addressees to perform some principled course of action; openly intending to inspire addressees to act on the principles; and intending that addressees' recognition of the intentions to urge and inspire creates reasons to grant a sympathetic hearing to what the speaker has to say. We then show that the theory explains the design of Abraham Lincoln's Cooper Union address. By describing the normative structure of exhorting, we add to the inventory of reasons why social actors make arguments—e.g., rationally resolving differences of opinion, justifying belief or action, displaying identity, expanding an agenda, and more (Asen 2005; Hample and Irions 2015). In addition, we continue a line of research showing the relationship of making arguments to master speech acts such as proposing and accusing (Jacobs 1989; Innocenti and Kathol 2018; Kauffeld 1998). ${ }^{1}$ Further, our analysis of Lincoln's exhortation follows historical and contemporary rhetorical theorizing (Conley 1984) showing that making arguments may be analyzed as a strategic maneuver (van Eemeren and Houtlosser 2000) designed to inspire principled action.

\section{Normative pragmatic theory}

${ }^{1}$ We use the phrase "making arguments" and related terms such as "argumentation" in the sense of O'Keefe's (1982) "argument 1 -making." 
Normative pragmatic theory explains why speakers can reasonably expect their messages to secure intended responses from addressees - e.g., to consider a proposal (Kauffeld 1998), to defer to an expert (Goodwin 2011), to accede to demands (Innocenti and Kathol 2018). The accounts are based on, first, norms brought to bear by making utterances intended to secure responses from addressees and, second, practical reasoning underlying those utterances. ${ }^{2}$ Normative pragmatic theory is based on a Gricean analysis of utterance-meaning, or what it means to seriously say and mean something. In what follows we first outline a Gricean analysis of utterance-meaning and then the underlying practical calculation that explains why a speaker can reasonably expect making utterances to secure intended responses from addressees.

\subsection{Gricean analysis of utterance-meaning}

We describe the analysis of utterance-meaning that follows as Gricean because it is based primarily on Grice's work in the philosophy of language but also on the work of others who added important components to Grice's analysis. The basic question Grice's analysis of utterance-meaning addressed was, What does it mean to seriously say and mean something? Grice (1957; 1969; Strawson 1964) answered the question in terms of reflexive speaker intentions, and Stampe (1967) explained Grice's insight that addressees' recognition of the speaker's intentions provides some reason for them to respond as the speaker intends. In what follows we sketch the analysis in order to illustrate the basic philosophical grounding of normative pragmatic theory outlined in the following subsection. ${ }^{3}$

Grice's analysis of utterance-meaning in his foundational essays "Meaning" (1957) and "Utterer's Meaning and Intention" (1969) is based on a fundamental insight that some utterance-meaning can be accounted for in terms of speaker intention. Over time Grice's analysis became increasingly complex as he addressed objections and counter-examples. We sketch the version comprising modifications he made in 1969 in to his initial 1957 analysis in

\footnotetext{
${ }^{2}$ Researchers who approach argumentation from a pragma-dialectical perspective have also described their theorizing as normative pragmatic and also make use of speech act theory in developing pragma-dialectical theory (e.g., van Eemeren and Grootendorst 1984; van Eemeren and Grootendorst 2004; van Eemeren, Grootendorst, Jackson, and Jacobs 1993). Whereas pragma-dialectical theory is based on integrating Grice's maxims with Searle's conditions for the performance of speech acts (e.g., Andone 2013; Houtlosser 1998; Snoeck Henkemans 2014), normative pragmatic theory is based on Grice's analysis of utterance-meaning $(1957 ; 1969)$ as amended and explained by Strawson (1964) and Stampe (1967). Normative pragmatic theory explains why a speaker can reasonably expect her utterance to secure her intended response from addressees without recourse to a notion of rules applied to a communicative interaction (Kauffeld 1987; Kauffeld 2009b; Strawson 1964). Instead, a normative pragmatic account explains or makes intelligible how social actors themselves design messages that regulate the activity (e.g., Jacobs 1989; 2000; 2006).

${ }^{3}$ See Kauffeld 1987; 2001; 2009a; 2009b for more detail on Grice's analysis.
} 
response to Strawson (1964) because this version and discussion of it by Stampe (1967) philosophically ground normative pragmatic theory.

In Grice's analysis, a speaker means something by uttering $u$ if and only if for some addressees she utters $u$ with the following reflexive intentions (Grice 1957, 383-385; Grice 1969, 151, 156; Strawson 1964, 447; Stampe 1967, 31-32):

The speaker intends ${ }_{1}$ (or at least acts as if she intends ${ }_{1}$ ) that addressees respond that $p$; The speaker intends ${ }_{2}$ (or at least acts as if she intends $)_{2}$ ) that addressees recognize the speaker's intention ${ }_{1}$; The speaker intends ${ }_{3}$ (or at least acts as if she intends ${ }_{3}$ ) that addressees recognize the speaker's intention ${ }_{2}$; The speaker intends 4 (or at least acts as if she intends 4 ) that addressees' recognition of the speaker's intentions provides addressees with some reason for responding that $p$.

Put differently, a speaker who seriously says and means something — who utters something with the intention ${ }_{1}$ that addressees respond in a particular way—also intends $s_{2}$ that addressees recognize her intention ${ }_{1}$, and intends that $_{3}$ addressees recognize that she intends $s_{2}$ them to recognize her intention ${ }_{1}$. Further, the speaker intends 4 that addressees' recognition of these intentions provides some reason for addressees to respond as the speaker intends ${ }_{1}$.

Grice's analysis accounts for utterance-meaning in terms of reflexive speaker intentions rather than convention (Stampe 1967; Stampe 1975; Strawson 1964). As Jacobs $(1989,361)$ has noted about a "conventionalist understanding," "Speech acts have the force that they do and are constituted by the conditions that they have because that is how the game is played. There is no deeper rationale or functional design.” But by accounting for utterance-meaning in terms of intention, Grice orients students of argumentation toward deeper rationales for actual message design or, in other words, ethical, moral, and pragmatic explanations why communication strategies may reasonably be expected to secure intended responses. The centerpiece of Grice's analysis is the accountability generated by intention ${ }_{3}$. By deliberately, openly intending her utterances to secure a particular response from addressees, a speaker makes herself accountable for obligations and responsibilities she undertakes just by making the utterance. In this analysis undertaking and discharging obligations, responsibilities, and the like explains why a speaker can reasonably expect her utterances to secure some predictable response. The following subsection explains that point in more detail.

\subsection{Basic normative pragmatic theory}


In what sense does recognition of reflexive speaker intentions provide some reason for addressees to respond in accord with the speaker's primary intention? First, Stampe (1967) follows Peirce in noting that even the basic communicative act of asserting with the intent of securing addressees' belief involves the speaker assuming responsibility for the veracity of the utterance, a feature of utterance-meaning that accounts for reactive attitudes toward lying, misleading, deceiving, and the like. So if a speaker successfully manifests the intention 2 that addressees recognize her intent $t_{1}$ to influence them to believe her utterance, then addressees recognize the speaker undertaking responsibility for the veracity of her assertion and her willingness to risk addressees' resentment if it turns out she is lying, misleading, and the like. So, second, a speaker who gets addressees to recognize her intent 2 gives addressees some reason — namely, that she would not risk their resentment unless she had met the responsibility that she undertook just by asserting — to respond by believing the assertion as the speakers intends ${ }_{1}$. In short, a speaker also intends $s_{3}$ addressees to recognize her intent $t_{2}$ in order to secure the response she intends ${ }_{1}$. This practical calculation explains the sense in which a speaker's intent 4 that addressees recognize her intentions provides some reason for addressees to respond as the speaker intends ${ }_{1}$. Thus, a Gricean account of utterance-meaning provides an account of illocutionary force not in terms of following conventions but in pragmatic terms (Jacobs 1989; Kauffeld 1987; Kauffeld 2009b; Stampe 1975; Strawson 1964).

The sorts of reasons created just by seriously saying and meaning some utterance may be described as presumptions, where presumptions are inferences taken by reason of the risk of resentment (Kauffeld 1995; Kauffeld 1998; Kauffeld 2003; Moldovan 2016). Examples include a presumption of veracity (addressees presume a speaker would not risk resentment for lying unless she had made a responsible effort to ascertain the truth of her assertion), a presumption of fairness (addressees presume a speaker would not risk resentment for impugning somebody's character unless she had made a responsible effort to treat the person fairly), and a presumption of merit (addressees presume a speaker would not risk resentment for wasting their time unless she had made responsible efforts to say something meriting addressees' time and attention).

Because making an utterance involves the speaker deliberately and openly manifesting her intention to get addressees to respond and incurring responsibilities, making the utterance changes the context or "normative terrain" (Goodwin 2011, 291) such that addressees incur reciprocal responsibilities. Analogously, as setting up a line divider obligates theater personnel to act in accord with norms of queuing, so it obligates patrons to act in accord with them as well (Innocenti and Miller 2016). Consider the basic act of asserting with an intent to secure addressees' belief. 
The presumption of veracity is grounded in a norm that speakers ought to speak truthfully and not lie, deceive, mislead, and the like. The norm is reciprocal; as speakers ought to speak truthfully, so addressees ought not to be unduly skeptical, lie, mislead, willfully ignorant, and the like. So to avoid criticism for undue skepticism, lying, and so on, addressees can respond as the speaker intends, i.e, by believing the assertion.

Of course in many cases, securing belief or other intended responses is not that simple. The reasons created just by making a basic utterance may not be sufficient for securing the intended response. Addressees may choose to accept risks of criticism for not responding as the speaker intends, perhaps by arguing that some norm does not apply to them or is not relevant in the circumstances. For example, even though any serious assertion generates a presumption of veracity, addressees may calculate that any risk of criticism for undue skepticism is mitigated by evidence they have found that is contrary to the speaker's assertion. Consider a case where a speaker asserts, "One and a half million people attended the presidential inauguration. Anyone who says fewer attended is a liar! Fake news!" The speaker deliberately and openly intends that addressees believe the assertion, vividly engages a presumption of veracity, and thereby changes the context such that addressees incur a reciprocal responsibility to not be unduly skeptical, willfully ignorant, and the like. But addressees may choose to take that risk; they may not respond with belief as the speaker intends. They may have strong grounds for skepticism so calculate that the potential risk of criticism for undue skepticism or willful ignorance is low. In fact, they may proffer grounds to support their skepticism. In doing so, they engage the presumption of veracity and change the normative terrain such that the first speaker must provide grounds or risk resentment for lying, willful ignorance, and the like.

In short, normative pragmatic theories explain why a speaker can reasonably expect just her utterance to secure her intended response from addressees in pragmatic terms of manifest speaker intentions and presumptive inferences underlying those intentions. Just by making utterances deliberately and openly, a speaker creates two reasons for addressees to respond as she intends. First, addressees can reason that the speaker would not deliberately, openly incur responsibility for living up to some norm unless she planned to meet it. Second, addressees can reason that they can avoid criticism for not living up to a reciprocal norm by responding as the speaker intends.

\section{Normative pragmatic theory of exhorting}

\subsection{Conceptual analysis of exhorting}


We submit that exhorting comprises three necessary components: making statements openly urging addressees to perform some principled action; manifestly intending to inspire addressees to act on their duty, commitment, obligation, and the like; and speaking with the intention that addressees' recognition of the speaker's open intention to urge addressees to act and overt effort to inspire addressees' performance creates reasons for granting a sympathetic hearing to what the speaker has to say. In this subsection we make a case for this normative structure and in the next subsection explain the underlying pragmatics.

The first necessary component of exhorting is making an utterance urging addressees to perform some principled action. We would regard it as odd were a speaker to say, "I exhort you to go to the polls and vote today, but I am not saying that you ought to vote." Moreover, to exhort, the speaker must come out and say that addressees are to perform the principled action. One may implicate things by exhorting, but one cannot exhort by merely implicating. Someone who said, "Perhaps you should vote," "It could be that you are to vote," and the like could hardly be described as exhorting addressees to vote.

However, exhorting requires more than urging addressees to perform some principled action. A speaker might say, "It is clear you are to vote; but whether you actually vote is up to you," but it would be odd to describe just that utterance as exhorting rather than, say, advising. Just an utterance stating that addressees are to perform some principled action could also be a command or some other imperative. A second necessary component is a manifest intention to inspire addressees to act on the principle or, put differently, an open intention of drawing forth, eliciting, or arousing an intentional/affective orientation corresponding to the call to action. An utterance like "I exhort you to stand firm, but I am not trying to get you to muster the courage to do it" is incoherent.

Intentional/affective orientations include alert, resolved, vigorous, energetic, cautious, courageous, compassionate, strenuous, and more. For example, a speaker might exhort addressees to resolutely pursue a graduate degree or cautiously approach driving in a snowstorm. These intentional/affective orientations admit various degrees. A speaker may exhort addressees to undertake graduate study resolved to see it through, but may also exhort addressees to undertake that course firmly resolved to complete it. Likewise, a speaker may exhort addressees to drive in snow cautiously, or to be extremely cautious. The fact that these intentional/affective orientations may vary in degree opens the possibility that, with respect to each, one may be inspired. Inspiration may be a complicated and in some respects mysterious matter, but it always involves some kind of heightening or elevation. Thus what a 
speaker says and how may be designed to inspire addressees to produce a highly energetic and/or vigorous performance.

The third necessary component of exhorting is that the exhorter speaks with the intention that addressees' recognition of the speaker's open intentions to urge and inspire addressees to perform some principled action creates reasons for addressees to grant a sympathetic hearing to what the speaker has to say. As proposers may aim to secure tentative consideration of a proposal more so than immediate adoption (Kauffeld 1998), or indeed speakers generally may aim to secure some sort of intermediate response before acting such as wondering, considering, weighing evidence, and the like (Pinto 1991), so exhorters may aim to secure a response intermediate to action, namely a sympathetic hearing. An audience can grant a sympathetic hearing but is not therefore committed to acting.

What is a "sympathetic hearing"? Following recent work in moral philosophy and political theory on Adam Smith's account of sympathy (e.g., Darwall 2013; Frazer 2010), we use the expression "sympathetic hearing" in the sense of speaker and addressees sharing a warranted harmony of feeling in reacting to a situation. Sympathetic addressees do not merely hear and understand what a speaker says while recognizing the feelings animating the speaker's utterances. Sympathetic addressees' apprehension of what the speaker says shifts from this relatively objective orientation and takes on something like what Strawson (1974) has called a reactive attitude. A reactive attitude is not emotional contagion; instead, addressees apprehend what the speaker says while experiencing something of the feelings animating the speaker's utterance. Externalizing a sympathetic hearing may involve addressees saying they see the speaker feels angry (or some other moral sentiment) about the situation and they appreciate and indeed share her anger.

The intention to create reasons for granting a sympathetic hearing to what the speaker has to say is conceptually necessary for distinguishing exhorting from mere haranguing. Both exhorting and haranguing may issue from the speaker supposing addressees are not living up to their proper commitments and duties, and both may voice disapprobation of the relevant failings. But the harangue is essentially an angry diatribe (tirade, rant) that is largely indifferent to soliciting a favorable reception from addressees. Indeed, in some cases a negative or hostile response could be interpreted by the speaker as evidence that she is on the side of truth and right (Jacobs 1983; van Eemeren, Grootendorst, Jacobs, and Jackson 1993, ch. 7). An exhorter, in contrast, cannot coherently express indifference about addressees' reception of her urging. We would find it odd were a speaker to say, "I do not care whether you turn a deaf ear on what I have to say; I exhort you to do your very best in this afternoon's contest.” 
What exactly are the reasons created by deliberately, openly urging and attempting to inspire addressees to perform some principled action? The answer involves describing the pragmatics of exhorting. Before turning to that task, we note the adequacy of our conceptual account. If a speaker acknowledges she is openly attempting to elicit a sympathetic hearing for utterances manifestly designed to urge and inspire addressees to perform a principled action, we would regard as odd a denial on her part that she is exhorting addressees to adopt that course of action. We might well accept such a denial from a speaker who is covertly trying to urge and inspire addressees to execute a course of action, but where a speaker openly speaks with such intentions, she is transparently attempting to exhort addressees.

\subsection{Pragmatics of exhorting}

The presumptions engaged just by exhorting serve as reasons for granting a sympathetic hearing. Speakers engage presumptions by undertaking and discharging obligations. What obligations do exhorters undertake and what presumptions do they engage?

Fundamentally, an exhorter undertakes an obligation to speak truthfully. Utterances that are not truthful lack persuasive force because addressees can easily dismiss them as lies. Undertaking an obligation to speak truthfully generates a presumption of veracity: the speaker would not risk criticism for lying or ignorance unless she had made responsible efforts to ascertain the veracity of her utterances. But just that presumption of veracity is characteristically not sufficient for securing a sympathetic hearing in circumstances where addressees are reluctant to act on some principles or duties. What other obligations do exhorters undertake just by exhorting, and what presumptions do they engage?

First, making utterances urging addressees to perform some principled action obligates a speaker to have made responsible efforts to ascertain the urgency of performing it, where urgency may involve immediate, pressing, or imperative need. If addressees ask the speaker to explain why they ought to perform some principled action, the speaker is obligated to provide reasons why they ought to act. An exhorter cannot coherently refuse to do so; for example, she cannot coherently say, "I exhort you to stand firm, but I can't tell you why you should," or "I exhort you to stand firm, and I have a good reason why you should, but it is not urgent." So exhorting engages a presumption that the speaker would not risk criticism for wasting addressees' time, poor judgment, questionable morality, and the like unless she had made responsible efforts to ascertain what moral course of action ought to be 
performed in the situation. Other things being equal, if the speaker's take on the urgent need for principled action seems mistaken, morally questionable, and the like, addressees can dismiss her exhortation with impunity. ${ }^{4}$

A potentially efficacious strategy for securing a sympathetic hearing, then, involves delineating a situation indicating the urgency of performing some principled action. Other things being equal, the more accurately, vividly, and the like the exhorter delineates the scene, the more she makes herself accountable to addressees for her moral bearing and therefore the more reason she creates for addressees to at least grant her exhortation a sympathetic hearing. At the same time, addressees cannot fail to recognize what the speaker sees or fail to share the speaker's feelings about the situation without risking criticism for questionable morality, short-sightedness, and the like. To avoid risks of criticism, they can grant a sympathetic hearing to what the speaker has to say.

Another obligation exhorters undertake is connected to their overt efforts to inspire addressees to act $—$ to arouse an intentional/affective orientation corresponding to the call to action. Those efforts obligate an exhorter to have carefully considered both the situation calling for action and addressees' circumstances, specifically constraints inhibiting their performance of the action, because she is making a claim on how addressees ought to orient toward acting. An exhorter cannot coherently say, "I exhort you to go to the polls and vote, and I see that it is not possible for you to get to the polls." Attempts to inspire may fall flat if exhorters fail to show they recognize and appreciate the difficulties of addressees' circumstances. So exhorting engages a presumption that the speaker would not risk criticism for self-righteousness, pretention, fanaticism, and the like unless she had made responsible efforts to understand and appreciate addressees' difficulties in performing some principled action. Other things being equal, addressees can dismiss with impunity an exhortation that misses the mark in efforts to inspire, perhaps saying the speaker is out of touch with their reality, has alienated them, is insufferable, smug, and so on.

A potentially efficacious strategy for securing a sympathetic hearing, then, involves delineating a situation indicating the propriety of the intentional/affective orientation toward the principled action. The greater the difficulties and constraints faced by addressees, the greater the efforts necessary to inspire them to act, so the greater

\footnotetext{
${ }^{4}$ We maintain that exhortations must urge and inspire principled action, a position compatible with the fact that news sources have described as exhortation some of U.S. President Donald Trump's calls to deplorable action (Hoefler 2016; Sweeny 2017). We believe utterances such as a call to "get "em" (protestors) at one of his March 2016 presidential campaign rallies are more accurately described as "inciting violence" than "exhorting violence," as indicated by both public outrage at Trump's calls to violent action and questions about whether Trump "incited" violence. Nonetheless, even if one wants to describe calls to deplorable action as exhortation, we submit that such exhortations may not be practically efficacious because they are easy to dismiss with impunity as immoral, unethical, wrong, not the right thing to do, and so on (see also Cooper and Zeleny 2011). As arguments can be weak or poor, so can exhortations.
} 
the risks of criticism undertaken by the exhorter for foolish pretension, insufferable self-righteousness, fanaticism, and the like, so the more reason she creates for addressees to grant her exhortation a sympathetic hearing. At the same time, addressees cannot fail to recognize and partake of the speaker's intentional/affective orientation without risking criticism for moral apathy, lack of courage, weak will, or some other relevant moral, ethical shortcoming because the speaker's strategies make visible and therefore make addressees accountable for recognizing the propriety of the intentional/affective orientation. To avoid that criticism, they can grant a sympathetic hearing to the speaker's exhortation — can recognize and partake in the moral sentiments displayed by the speaker.

Of course to avoid risks a speaker creates just by exhorting, addressees need not necessarily grant a sympathetic hearing. They can respond with a message designed to show, say, a lack of urgency to act or a need to perform a different, more principled action. They can respond with further information about their own circumstances and constraints inhibiting some principled action. Consequently, it is in the speaker's interest to design a message that forestalls the possibility of addressees' easy dismissal of the exhortation. This circumstance accounts for why speakers who exhort characteristically say more than "Act!" In fact, this helps to account for why a speaker exhorts at all when doing so puts her at risk of criticism for questionable morality, fanaticism, and more. She must exhort in order to make it risky for addressees to not act on some principle because, other things being equal, in the absence of exhortation, addressees can say with impunity that they did not see an urgent need to rouse themselves to perform some principled act.

In short, presumptions engaged just by exhorting — just by making utterances deliberately, openly designed to urge and inspire performance of some principled action — are reasons for granting a sympathetic hearing.

Exhorting licenses addressees to presume the exhorter would not risk criticism for questionable morality or foolish pretension unless she had made responsible efforts to ascertain what principled action was called for and what constraints inhibited addressees' performance. Norms brought to bear by engaging presumptions are reciprocal; as exhorters make visible their responsible efforts to act in principled ways, they communicatively make addressees accountable for seeing and likewise making responsible efforts to act in principled ways. Whereas an account of exhorting featuring "emotional contagion" would describe the potential efficacy of exhortation in terms of affect shared by speaker and addressees, a normative pragmatic account explains the potential efficacy in ethical, moral, and practical terms and, further, can explain why some highly emotionally-charged appeals can reasonably be expected to secure an intended response while others can be easily dismissed as foolish pretension. 


\section{Case study}

Abraham Lincoln's 1860 speech at Cooper Union illustrates the explanatory power of a normative pragmatic theory of exhorting. The speech is a clear case of exhortation, and scholars concur that it is a literary and political masterpiece that helped to secure Lincoln's nomination as Republican party candidate for United States President (Wilentz 2009) and perhaps made him president (Corry 2003; Holzer 2004). Our goal is not to provide an exhaustive interpretation of the speech but to test whether and to what extent normative pragmatic theory can explain why Lincoln's exhortation secured a sympathetic hearing.

Despite Lincoln's conventional and politically astute disavowals as late as February 1860 in response to proposals that he run for president (Current 2009), his Cooper Union address is part of his campaign to be selected as the Republican nominee for United States President and then to defeat Democratic candidate Stephen Douglas in the national election. His immediate audience was the Young Men's Central Republican Union, but Lincoln knew the speech would be printed in newspapers and reach a larger national audience (Holzer 2004). Lincoln concludes the speech by exhorting Republicans "to do our duty as we understand it" $(1860,284)$. He urges them to take a principled stand against the spread of slavery: "Wrong as we think slavery is, we can yet afford to let it alone where it is, because that much is due to the necessity arising from its actual presence in the nation" $(1860,283)$. Lincoln implies that electing him will enable Republicans to do their duty—-that as long as votes by Republicans will prevent slavery from spreading, Republicans ought not "cast our votes with [Democrats'] view, and against our own" (1860, 283). Lincoln describes Democratic candidate Douglas' popular sovereignty position (inhabitants of territories ought to decide whether to join the union as a free or slave state) as a "don't care" policy because calling for inhabitants of territories to decide on the status of slavery implies Douglas does not care how inhabitants vote $(1860,283)$.

Lincoln does not advocate abolition of slavery_-immediate emancipation and full political, civil rights for free people — and could not seriously contend for national political office if he did because he would be dismissed as too radical. Lincoln had to exhort Republicans to stand against the spread of slavery in a way that enabled him to avoid charges that his rhetoric was incendiary. One of the main contenders for the Republican nomination, William Seward, was seen by some Republicans as not a viable choice because remarks he made in earlier speeches were considered to be too radical, making him vulnerable to criticism for inciting violence and disunion (Egerton 2010; 
Leff and Mohrmann 1974). In short, Lincoln had to inspire Republicans to adhere to an anti-slavery position and not waver in their commitment to it—not vote instead for a candidate supporting a popular sovereignty position.

Lincoln's speech comprises three sections: a case against Douglas' position that the founding fathers are on the side of Democrats rather than Republicans (1860, 252-267), a direct address to the people of the South (1860, 267-280), and a direct address to Republicans (1860, 280-284). In the third section he deliberately, openly exhorts Republicans: "let us stand by our duty, fearlessly and effectively" $(1860,283)$ and "LET US HAVE FAITH THAT RIGHT MAKES MIGHT, AND IN THAT FAITH, LET US, TO THE END, DARE TO DO OUR DUTY AS WE UNDERSTAND IT [all capitals in original]" $(1860,284)$. The third section is significantly shorter than the first two probably because in the first two sections he has already undertaken and discharged obligations connected with exhorting and vividly warranted a sympathetic hearing. The contours of his basic strategy for warranting a sympathetic hearing are apparent in the third section. He deploys argumentation to animate resentment for the rhetorical conduct of Douglas and the people of the South and reverence for the founding fathers in order to inspire Republicans to adhere to an anti-slavery position rather than waver in that commitment and vote for Douglas and popular sovereignty.

Lincoln urges Republicans to "calmly consider" demands of the people of the South, but when he reasons about those demands he concludes the only way to satisfy them is to perform a morally questionable rhetorical action: "cease to call slavery wrong and join them in calling it right" (1860, 280, 281). He further urges Republicans, "Let us be diverted by none of those sophistical contrivances wherewith we are so industriously plied and belabored," including Stephen Douglas' advocacy of "a policy of 'don't care' on a question about which all true men do care" as well as "Union appeals beseeching true Union men to yield to Disunionists, reversing the divine rule, and calling, not the sinners, but the righteous to repentance —-[prolonged cheers and laughter,] such as invocations to Washington, imploring men to unsay what Washington said, and undo what Washington did" (1860, 283). Thus Lincoln displays resentment for the rhetorical conduct of the people of the South and the Democratic candidate and reverence for founding father George Washington, and enacts preferable rhetorical conduct.

In what follows we argue that the first two sections of the speech are designed to warrant a sympathetic hearing for his exhortation — to create reasons for Republicans to say they share Lincoln's feelings about the situation and understand why he exhorts them to take a principled stand against the spread of slavery rather than 
settle for a “don't care" position. We show that Lincoln uses argumentation as a strategy for arousing intentional/affective orientations toward Douglas, founding fathers, and the people of the South.

\subsection{Inspiring by arguing against Douglas}

In the first section of the speech Lincoln considers the accuracy of Douglas' claim that Democrats hold the same position as the founding fathers on the question of whether the federal government can control slavery in federal territories. Lincoln argues the founding fathers' position is the opposite of what Douglas claims and meticulously makes the case by defining the issue and who the founding fathers are, and reporting how they voted on each occasion the issue was in question. Thus Lincoln begins to delineate the situation indicating the urgency for Republicans to do their duty to prevent the spread of slavery by making arguments. As critics of the speech have noted, Lincoln's presentation of grounds, "while enmeshed in an incisive logical and linguistic structure," is at the same time "fiercely emotional" (Leff and Mohrmann 1974, 351). But "emotional contagion" does not adequately account for how Lincoln's argumentation is designed to work because belief and emotion are inextricably linked. We submit that Lincoln makes arguments to arouse an intentional/affective orientation—reverence for the founding fathers and resentment against Douglas — and inspire addressees to adhere to an anti-slavery position.

The structure of Lincoln's argumentation in this section of the speech is convergent. Lincoln first discusses six occasions when original framers of the United States Constitution acted on the question, and repeatedly concludes almost all indicated nothing forbade them from prohibiting slavery in federal territories $(1860,258$; see also 254-55, 257, 259, 260). He then considers the positions of two other sets of framers: those who left no record on the direct question, and those in the first Congress. He concludes by repeating that "a clear majority of the wholecertainly understood that no proper division of local from federal authority, nor any part of the Constitution, forbade the Federal Government to control slavery in the federal territories; while all the rest probably had the same understanding" $(1860,263)$. Finally, he considers whether amendments to the U.S. Constitution can serve as grounds for claiming federal control of slavery in federal territories is unconstitutional and concludes, based on the U.S. Congress passing an act enforcing prohibition of slavery in the Northwest Territory, Douglas' claim to be on the side of the founding fathers is false. Further, Lincoln "def[ies] any man to show that any one of them [founding fathers] ever, in his whole life, declared that, in his understanding, any proper division of local from federal authority, or any part of the Constitution, forbade the Federal Government to control as to slavery in the federal 
territories" $(1860,265)$. He repeats the conclusion again as he "def[ies] any one to show that any living man in the whole world ever did, prior to the beginning of the present century, (and I might almost say prior to the beginning of the last half of the present century,) declare that, in his understanding, any proper division of local from federal authority, or any part of the Constitution, forbade the Federal Government to control as to slavery in the federal territories" $(1860,265-66)$. How is Lincoln's argumentation designed to inspire Republicans to adhere to an antislavery position— to not waver in their commitment to that position by voting instead for Douglas and popular sovereignty?

First, by using the presentational device of repeating the conclusion about how the founding fathers voted, Lincoln deliberately, openly intends to arouse reverence for the founding fathers. He openly undertakes and discharges an obligation to have ascertained the propriety of reverence by bringing to bear a norm that addressees ought not unthinkingly, blindly revere the founding fathers. In order to "guard a little against being misunderstood," Lincoln explicitly states he does "not mean to say we are bound to follow implicitly in whatever our fathers did" but asserts that any supplanting of "the opinions and policy of our fathers in any case" should happen only "upon evidence so conclusive, and argument so clear, that even their great authority, fairly considered and weighed, cannot stand" $(1860,266)$. Thus Lincoln brings to bear a norm that reverence ought to be warranted and acts in accord with it, so communicatively creates conditions in which reverence for the founding fathers can legitimately ground inspired action.

Of course Lincoln's claim that Republicans are on the side of the founding fathers is not without difficulties. The U.S. Constitution explicitly provided for the return of fugitive slaves, and some founding fathers were slaveholders. But Lincoln presents "Constitutional grounds for identification with the fathers, and he expands that association to the point that it offers stable moral ground for the party to repel attacks and to conceive its mission in principled, conservative terms" (Leff 2001, 238). In short, Lincoln can reasonably expect convergent argumentation, which repeats a conclusion about the founding fathers' position on whether the federal government could control slavery in federal territories, to secure a sympathetic hearing. Deploying the strategy makes it difficult for Republicans to dismiss the exhortation with impunity by saying, for example, that Lincoln fails to understand and respect the principled action warranted by the founding fathers' votes. Lincoln effectively adapts to his Republican audience in selecting the topic of reverence for the founding fathers. Republicans who want to claim reverence for the founding fathers as inspiration for their actions would need to at least grant a sympathetic hearing 
to an exhortation urging them to act in accord with principles sanctioned by the founding fathers-would need to say they recognize and share Lincoln's mindful reverence — or risk criticism for impiety or willful blindness to the founding fathers' position.

Second, by increasing the intensity of his argumentation with each repetition, Lincoln deliberately, openly intends to arouse resentment against Douglas. One critic has described this section of the speech as a "rhetorical delight" and speculated that Lincoln likely altered the tone of the phrase with each repetition, "intoning it here with mock gravity, there with a sarcastic edge, and here again with a laugh of disbelief" (Holzer 2004, 121, 122). How is the presentational device of increasing intensity designed to inspire addressees to not waver from their Republican anti-slavery position and grant his exhortation a sympathetic hearing?

By repeating the point with increasing emotional intensity, Lincoln vividly, deliberately, openly displays grounds for resentment against Douglas but also restrained partisanship. In the scene Lincoln delineates, Douglas spectacularly fails to make good on a claim to be on the side of the founding fathers. Lincoln indirectly impugns Douglas' rhetorical conduct as he concludes the first section of the speech by making determinate procedural, political norms of resolving conflict: if anybody "sincerely believes" that the federal government may not prohibit slavery in federal territories, "he is right to say so, and to enforce his position by all truthful evidence and fair argument which he can. But he has no right to mislead others, who have less access to history, and less leisure to study it, into the false belief," by "substituting falsehood and deception for truthful evidence and fair argument" (1860, 266). Lincoln displays a "crying foul” strategy (Innocenti 2011) to warrant resentment against Douglas: he makes a key norm determinate; makes manifest the badness of Douglas' rhetorical conduct; and shows that he is exercising forbearance - that Douglas can yet try to enforce his position by truthful evidence and fair argument. As a result Lincoln's resentment culminates not in fury at a vicious liar or malevolent indifference to slavery but in ridicule for a fool who could yet make amends by using truthful evidence and fair argument.

Recall that Lincoln needs to exhort Republicans and avoid charges of inciting violence and disunion. A brief look at the well-known "Brutus is an honorable man" speech by Antony in Shakespeare's Julius Caesar enables us to make a comparative judgment about Lincoln's strategy by considering how Lincoln could have manifested resentment against Douglas but did not (Jacobs 2000). In Act 3, Scene 2, Shakespeare's Antony repeats "Brutus is an honorable man" in a scene of rendering "public reasons" for the murder of Caesar. The irony of Antony's statement and the intensity of his resentment of Brutus for slaying Caesar increase with each iteration. 
Antony's use of a conditional — "if I were disposed to stir / Your hearts and minds to mutiny and rage"-may be designed to enable him to plausibly deny an intention to incite violent retribution. But Antony's exclamations and vivid description of the slaying of Caesar belie the conditional, and indeed Shakespeare's citizens call for revenge, killing, slaying, burning.

While at first hearing Lincoln's dramatic repetition may sound akin to Antony's, significant differences between them bring into sharp relief the intentional/affective orientation Lincoln takes responsibility for holding and attempting to inspire in addressees while avoiding a charge of inciting violence and disunion. First, while the sentence Antony repeats is ironic - he says the opposite of what he means, and his true meaning is not immediately apparent - the sentence Lincoln repeats is a direct, literal conclusion based on historical research. Second, while Antony deploys exclamations and vivid descriptions of Caesar's murder, Lincoln deploys argumentation; he carefully, deliberately, openly presents historical evidence and draws a conclusion that contradicts Douglas' claim. Third, while Antony impugns Brutus by name — indeed, Brutus is the subject of the sentence he repeats — in this first section of the speech and after he begins presenting historical evidence, Lincoln refers to Douglas only twice: once by name and once indirectly. Of course "the fact that the 'Little Giant' is the object of the onslaught that ensues will be clear to everyone in the hall" (Holzer 2004, 121), but Lincoln deploys argumentation so can plausibly lay claim to restrained partisanship. And fourth, while Antony's repetitions culminate in rage and desire for vengeance, Lincoln's culminate in ridicule and a call for people who disagree with each other to play by the rules of debate.

In sum, Lincoln can reasonably expect convergent argumentation of increasing emotional intensity to secure a sympathetic hearing. With each repetition, Lincoln increases his vulnerability to criticism for mocking and insulting Douglas. On one hand, mocking and insulting are commonplace and conventional in a political campaign. But on the other hand, given the political situation, Lincoln needs to display moderation. So increasing the intensity of his case against Douglas involves conspicuously risking his claim to skilled advocacy and party leadership and thus creates more reason to grant his exhortation a sympathetic hearing. At the same time, Lincoln effectively adapts to his Republican audience in selecting the topic of resentment against Douglas. Deploying argumentation makes it difficult for Republicans to dismiss the exhortation with impunity by saying, for example, that Lincoln is just inciting or exacerbating partisan rancor, because they would risk criticism for not seeing the need for truthful evidence and fair argument in order to give positions and proceedings the political legitimacy necessary for 
preserving peace and maintaining the union of states. To avoid that criticism, they can grant a sympathetic hearing by saying, for example, that they recognize and share Lincoln's resentment at Douglas' rhetorical conduct.

\subsection{Inspiring by arguing against the people of the South}

In the second section of the speech, Lincoln apostrophizes the people of the South. He directly addresses them as "if they would listen —as I suppose they will not" $(1860,267)$. We agree with scholars who hold that Lincoln is not in fact speaking directly to the people of the South in order to assuage slaveholders' fears that a Republican, anti-slavery chief executive would abolish slavery. Instead he is continuing to exhort northerners and people in border states (Briggs 2005; Holzer 2004; Leff and Mohrmann 1974) to support a Republican anti-slavery position rather than a Democratic popular sovereignty one. We submit that Lincoln's apostrophe is designed to arouse reverence for the founding fathers and resentment against the people of the South, and inspire them to adhere to the Republican anti-slavery position. Significantly, the main strategy Lincoln deploys as he apostrophizes is argumentation.

Lincoln structures this second section as a response to accusations by the people of the South against Republicans: they are sectional, revolutionary, make the slavery question prominent, and cause insurrections. Lincoln's broad strategies in this section are comparable to those in the first: he deploys argumentation to display grounds for his intentional/affective orientation. Lincoln's strategy of directly addressing the people of the South makes it difficult for Republicans to plausibly claim Lincoln is haranguing them (Republicans) for wavering in their stance against slavery or accusing them of moral weakness, and to dismiss his exhortation as self-righteous or alienating.

As he did with Douglas in the first section of the speech, in the second section Lincoln "cries foul" about the rhetorical conduct of the people of the South as part of his overt effort to inspire addressees to remain committed to an anti-slavery position. First, Lincoln makes norms of debate determinate and acts in accord with them. For example, at the outset of the section he states: "Bring forward your charges and specifications, and then be patient long enough to hear us deny or justify" $(1860,267)$. In addition, he makes determinate norms regarding burden of proof by stating, "You say we are sectional. We deny it. That makes an issue; and the burden of proof is upon you" $(1860,267)$. Making norms determinate and then living up to them continues to make manifest that Lincoln is playing by the rhetorical rules. 
Second, Lincoln deliberately, openly displays the badness of the rhetorical conduct of the people of the South. For example, according to Lincoln some people of the South "denounce [Republicans] as reptiles, or, at the best, as no better than outlaws" $(1860,267)$; "delight to flaunt in our faces the warning against sectional parties given by Washington in his Farewell Address" $(1860,268)$; "reject, and scout, and spit upon that old policy" of the founding fathers which would ground their claims to conservatism $(1860,269)$; "need to be told that persisting in a charge which one does not know to be true, is simply malicious slander" $(1860,270)$; and threaten to "break up the Union ... [with] a somewhat reckless sound" $(1860,274-75)$ akin to extortion $(1860,280)$. Lincoln's delineation of bad rhetorical conduct displays grounds for his resentment.

Significantly, Lincoln delineates the situation such that the problem is not the South's moral failure to recognize the humanity of Black people and inhumanity of slavery. Instead he faults the South for failing to act in accord with founding fathers who voted on the question of whether the federal government could control slavery in federal territories. For example, Lincoln reverses the charge of being revolutionary or destructive by calling on the people of the South to abide by principles of the founding fathers: "If you would have the peace of the old times, readopt the precepts and policy of the old times" $(1860,270)$. Likewise, Lincoln reverses the charge that Republicans make the slavery question more prominent than it formerly was by blaming the people of the South "who discarded the old policy of the fathers" $(1860,270)$. Responding to the charge that Republicans aided or encouraged John Brown's raid at Harper's Ferry, Lincoln replies that Republicans "hold to no doctrine, and make no declaration, which were not held to and made by 'our fathers who framed the Government under which we live"” $(1860,271)$. When considering the position that the U.S. Supreme Court's Dred Scot decision supports the view of slaves as property, Lincoln notes that in contrast to the division of opinion and mistaken views of some U.S. Supreme Court justices, “'our fathers, who framed the Government under which we live'- the men who made the Constitution — decided this same Constitutional question in our favor, long ago" $(1860,279)$ without division or factual mistakes. In fact, at the two points in the speech where Lincoln uses the word evil to describe slavery, he does so by attributing the moral stance to founding fathers $(1860,267,273)$. Likewise, in this second section of the speech when he describes slavery as wrong, he associates the moral stance with the founding fathers: "True, we do, in common with 'Our fathers, who framed the Government under which we live,' declare our belief that slavery is wrong; but the slaves do not hear us declare even this" $(1860,271-72)$. 
If Lincoln had manifested resentment against the South's immoral stance on slavery, then Republicans wavering in their commitment to an anti-slavery position could with impunity dismiss his exhortation on the grounds that they cannot share the intensity of a feeling that will threaten violence and disunion. Responding to accusations with "truthful evidence and fair argument" is the norm of argumentation and debate that Lincoln openly, deliberately brings to bear in the situation, and failures of the people of the South to live up to that norm ground feelings of resentment. Republicans cannot with impunity deny a sympathetic hearing to Lincoln's exhortation by saying they do not share his resentment about the South's rhetorical conduct, because saying so would put them at risk of criticism for condoning misconduct that threatens procedures established by the founding fathers for addressing political conflict and thus the integrity of the U.S. government.

Third, Lincoln displays that he exercises forbearance - that he is giving the people of the South a chance to adjust their tactics and respond appropriately with truthful evidence and fair argument and giving the political system established by the founding fathers a chance to work as it should. Lincoln displays forbearance at the outset of the apostrophe to the people of the South, thus making it conspicuous, open, and deliberate. We quote at length because the passage shows how Lincoln brings together features of a "crying foul" strategy we have separated analytically: making norms determinate, making manifest the badness of the South's rhetorical conduct, and showing he exercises forbearance. Lincoln first considers the charge that the Republican party is sectional. He explains that the people of the South "ought to have started" with "a discussion of the right or wrong of our principle" $(1860,268)$ :

If our principle, put in practice, would wrong your section for the benefit of ours, or for any other object, then our principle, and we with it, are sectional, and are justly opposed and denounced as such. Meet us, then, on the question of whether our principle, put in practice, would wrong your section; and so meet it as if it were possible that something may be said on our side. Do you accept the challenge? No! Then you really believe that the principle which 'our fathers who framed the Government under which we live' thought so clearly right as to adopt it, and indorse it again and again, upon their official oaths, is in fact so clearly wrong as to demand your condemnation without a moment's consideration. $(1860,268)$

First, Lincoln makes norms of debate and argumentation determinate as he defines the issue and calls on the people of the south to address it. Second, he displays the badness of the South's rhetorical conduct as they condemn the founding fathers' principle "without a moment's consideration." Thus Lincoln displays grounds for resentment 
about the South's rhetorical conduct and reverence for the founding fathers. The principle he takes responsibility for living up to is the founding father's position on whether the federal government can control slavery in the territories, and makes the topic not the injustice of slavery but whether the principle of antislavery "would wrong your section." Third, he shows he is exercising forbearance as he asks the people of the South to respond to his challenge even though he suggests he does not think it is possible for them to say something that would support a claim that the anti-slavery position harms the South. By exercising forbearance Lincoln displays a commitment to political, institutional procedures for resolving conflict. He displays that commitment even more vividly as he asks whether "the number of John Browns [would] be lessened or enlarged" by "forcing the sentiment" against slavery "out of the peaceful channel of the ballot-box, into some other channel" $(1860,274)$, namely military action.

Thus Lincoln delineates a situation where Republicans can occupy the political high ground with the founding fathers primarily by arguing well and voting. Lincoln can reasonably expect the apostrophe to the people of the South to secure a sympathetic hearing from Republicans. First, by undertaking and discharging obligations to argue truthfully, fairly, and appropriately, Lincoln licenses Republicans to presume Lincoln would not risk criticism for questionable morality or incendiary conduct unless he had responsibly ascertained the principled action called for in the circumstances. Second, in order to avoid criticism for questionable morality and condoning rhetorical conduct that would lead to violence and disunion, Republicans can grant Lincoln's exhortation a sympathetic hearing. As in the first section of the speech, in this second section argumentation is the main strategy for arousing intentional/affective orientations.

\section{Conclusions}

The normative structure of exhorting helps to account for the design of Lincoln's Cooper Union address. Lincoln makes statements openly urging and intending to inspire Republicans to adhere to an anti-slavery position, and intending that Republicans' recognition of those intentions creates reasons for them to grant his exhortation a sympathetic hearing. In this case externalization of a sympathetic hearing comprises statements semantically equivalent to recognizing and sharing Lincoln's resentment of the bad rhetorical conduct of Douglas and the people of the South, namely their failure to use truthful evidence and fair argument, and his mindful reverence of the founding fathers' position on the issue of whether the federal government could control slavery in federal territories. Lincoln warrants his feelings of resentment and reverence by arguing. Thus, our analysis indicates that as in 
proposing and accusing (Kauffeld 1998), so in exhorting arguing is a strategy that may be deployed in the service of a master speech act. Lincoln deploys argumentation to communicatively create conditions for the effective reception of his exhortation (cf. Jacobs 2006). We have not provided an exhaustive account of rhetorical strategies Lincoln deploys to influence Republicans, but we have shown the normative structure of exhorting accounts for the practical efficacy of Lincoln's speech.

We can imagine exhorters deploying strategic maneuvers other than argumentation to inspire principled action, such as telling stories. But in the case of Lincoln's Cooper Union address, a relevant, central moral sentiment is resentment about bad rhetorical conduct. Lincoln can reasonably expect the topic of resentment about bad rhetorical conduct presented in the form of arguing to influence Republicans who want to lay claim to trying to preserve peace and union, because arguing communicatively creates reasons for them to do so. First, the maneuver licenses Republicans to presume he would not risk criticism for displaying questionable moral judgment, inciting violence, alienating addressees, and the like unless he had made responsible efforts to ascertain the urgent need for principled action and to understand Republicans' difficulties in performing it. Second, Republicans can say they see and share Lincoln's resentment about bad rhetorical conduct in order to avoid criticism for questionable judgment and failing to recognize and participate in the very procedures - argumentation and debate - that constitute and give legitimacy to decisions made by governments based on the consent of the governed, that is, the form of government established by the founding fathers. Lincoln counts on the strategy of argumentation to bring to bear the norm that "power has to persuade in a reasonable way" (Iețcu-Fairclough 2009, 132), that is, political conflict in a representative democracy ought to be managed by participating in political procedures involving argumentation and debate. Failure to do so undermines government itself.

We submit that a normative pragmatic account of exhorting is preferable to an account featuring "emotional contagion" because it explains why social actors can reasonably expect their utterances to influence other social actors. If emotional contagion were the key mechanism, then we would expect to see exhorters routinely designing messages displaying affect only or primarily. But a quick perusal of civic speech illustrates that social actors routinely do more, fundamentally including presenting grounds for affect and, in doing so, undertaking ethical and moral obligations. A normative pragmatic account of exhorting can capture the range of communication resources that social actors bring to bear to influence other social actors, so can capture the complexity of human interaction better than a psychological account of emotion and belief only. 


\section{References}

Andone, C. 2013. Argumentation in political interviews: Analyzing and evaluating responses to accusations of inconsistency. Amsterdam: John Benjamins.

Asen, R. 2005. Pluralism, disagreement, and the status of argument in the public sphere. Informal Logic 25(2): 117137.

Black, E. 1965. Rhetorical criticism: A study in method. Madison: University of Wisconsin Press.

Briggs, J.C. 2005. Lincoln's speeches reconsidered. Baltimore: The Johns Hopkins University Press.

Conley, T.M. 1984. The enthymeme in perspective. Quarterly Journal of Speech 70(2): 168-187.

Cooper, H., and J. Zeleny. 2011, Jan. 13. Obama calls for a new era of civility in U.S. politics. New York Times. Retrieved from www.nytimes.com.

Corry, J.A. 2003. Lincoln at Cooper Union: The speech that made him president. Xlibris.

Current, R.N. 2009. The master politician. In The best American history essays on Lincoln, ed. S. Wilentz, 129-148. New York: Palgrave Macmillan.

Darwall. S. 2013. Honor, history, and relationship: Essays in second-personal ethics II. Oxford: Oxford University Press.

Eemeren, F.H. van, B. Garssen, E.C.W. Krabbe, A.F. Snock Henkemans, B. Verheij, and J.H.M. Wagemans. 2014. Handbook of Argumentation Theory. Dordreht: Springer.

Eemeren, F.H. van, and R. Grootendorst. 1984. Speech acts in argumentative discussions: A theoretical model for the analysis of discussions directed towards solving conflicts of opinion. Dordrecht: Foris.

Eemeren, F.H. van, and R. Grootendorst. 2004. A systematic theory of argumentation: The pragma-dialectical approach. Cambridge: Cambridge University Press.

Eemeren, F.H. van, R. Grootendorst, S. Jackson, and S. Jacobs. 1993. Reconstructing argumentative discourse. Tuscaloosa: University of Alabama Press.

Eemeren, F.H. van, and P. Houtlosser. 2000. Rhetorical analysis within a pragma-dialectical framework: The case of R. J. Reynolds. Argumentation 14(3): 293-305.

Egerton, D.R. 2010. Year of meteors: Stephen Douglas, Abraham Lincoln, and the election that brought on the Civil War. New York: Bloomsbury Press. 
Frazer, M. 2010. The enlightenment of sympathy: Justice and the moral sentiments in the eighteenth century and today. Oxford: Oxford University Press.

Goodwin, J. 2011. Accounting for the appeal to the authority of experts. Argumentation 25(3): 285-296.

Grice, H.P. 1957. Meaning. Philosophical Review 66(3): 377-388.

Grice, H.P. 1969. Utterer's meaning and intention. Philosophical Review 78(2): 147-177.

Hample, D., and A.L. Irions. 2015. Arguing to display identity. Argumentation 29(4): 389-416.

Hoefler, J. 2016, 10 Aug. Do menacing comments about Hillary Clinton cross the First Amendment line? Washington Post. Retrieved from www.washingtonpost.com.

Holzer, H. 2004. Lincoln at Cooper Union: The speech that made Abraham Lincoln president. New York: Simon and Schuster.

Houtlosser, P. 1998. Points of view. Argumentation 12(3): 387-405.

Ieţcu-Fairclough, I. 2009. Legitimation and strategic maneuvering in the political field. In Examining argumentation in context: Fifteen studies in strategic maneuvering, ed. F.H. van Eemeren, 131-151. Amsterdam: John Benjamins.

Innocenti, B. 2011. Countering questionable tactics by crying foul. Argumentation and Advocacy 47(3): 178-188.

Innocenti, B., and E. Miller. 2016. The persuasive force of political humor. Journal of Communication 66(3): 366385 .

Innocenti, B., and N. Kathol. 2018. The persuasive force of demanding. Philosophy and Rhetoric 51(1): 50-72.

Jackson, S. 1992. Virtual standpoints and the pragmatics of conversational argument. In Argumentation illuminated, ed. F.H. van Eemeren, R. Grootendorst, J. A. Blair, and C. A. Willard, 260-269. Amsterdam: SicSat.

Jacobs, S. 1983. When worlds collide: An application of field theory to rhetorical conflict. In Argument in transition: Proceedings of the third summer conference on argumentation, ed. D. Zarefsky, M.O. Sillars, and J. Rhodes, 749-755. Annandale: Speech Communication Association.

Jacobs, S. 1989. Speech acts and arguments. Argumentation 3(4): 345-365.

Jacobs, S. 2000. Rhetoric and dialectic from the standpoint of normative pragmatics. Argumentation 14(3): $261-286$. Jacobs, S. 2006. Nonfallacious rhetorical strategies: Lyndon Johnson's Daisy ad. Argumentation 14(3): 261-286.

Kauffeld, F.J. 1987. Rhetoric and practical necessity: A view for the study of speech acts. In Proceedings of the fifth SCA/AFA conference on argumentation: Argument and critical practices, ed. J.W. Wenzel, 83-95. Annandale: 
Speech Communication Association.

Kauffeld, F.J. 1995. On the difference between assumptions and presumptions. In Argumentation and values:

Proceedings of the ninth SCA/AFA Conference on Argumentation, ed. S. Jackson, 509-514. Annandale: Speech Communication Association.

Kauffeld, F.J. 1998. Presumptions and the distribution of argumentative burdens in acts of proposing and accusing. Argumentation 12(2): 245-266.

Kauffeld, F.J. 2001. Argumentation, discourse, and the rationality underlying Grice's analysis of utterance-meaning. In Cognition in Language Use, ed. T. E. T. Németh, 149-163. Antwerp: International Pragmatics Association.

Kauffeld, F.J. 2003. The ordinary practice of presuming and presumption with special attention to veracity and the burden of proof. In Anyone Who Has a View: Theoretical Contributions to the Study of Argumentation, eds. F.H. van Eemeren, J.A. Blair, C.A. Willard, and A.F. Snoeck Henkemans, 133-146.

Kauffeld, F.J. 2009a. Grice's analysis of Utterance-Meaning and Cicero's Catilinarian apostrophe. Argumentation 23(2): 239-57.

Kauffeld, F.J. 2009b. What we are learning about the pragmatics of the arguers' obligations? In Concerning Argument, ed. S. Jacobs, 1-31. Washington DC: National Communication Association.

Krause, S.R. 2002. Liberalism and honor. Cambridge: Harvard University Press.

Leff, M. 2001. Lincoln at Cooper Union: Neo-classical criticism revisited. Western Journal of Communication 65(3): 232-248.

Leff, M.C., and G. P. Mohrmann. 1974. Lincoln at Cooper Union: Rhetorical analysis of the text. Quarterly Journal of Speech 60(3): 346-358.

Lincoln, A. 1860. Cooper Union address. Reprinted in: H. Holzer (2004) Lincoln at Cooper Union: The speech that made Abraham Lincoln president, 249-284. New York: Simon and Schuster.

Marinelli, K. 2016. Revisiting Edwin Black: Exhortation as a prelude to emotional-material rhetoric. Rhetoric Society Quarterly 46(5): 465-485.

Moldovan, Andrei. 2016. Presumptions in communication. Studia Humana 5(3): 104-117.

O'Keefe, D.J. 1982. The concepts of argument and arguing. In Advances in argumentation theory and research, ed. J.R. Cox and C.A. Willard, 3-23. Carbondale: Southern Illinois University Press.

Pinto, R.C. 1991. Generalizing the notion of argumentation. In Proceedings of the Second International Conference 
on Argumentation, eds. F. H. van Eemeren, R. Grootendorst, J. A. Blair, and C. A. Willard, vol. 1, 137-146. Amsterdam: SIC SAT.

Pinto, R.C. 2007. Burdens of rejoinder. In Reason reclaimed: Essays in honor of J. Anthony Blair and Ralph H. Johnson, eds. H.V. Hansen and R.C. Pinto, 75-88. Newport News: Vale Press.

Shakespeare, W. n.d. Julius Caesar. Retrieved from http://shakespeare.mit.edu/julius_caesar/

Snoeck Henkemans, A.F. 2014. Speech act theory and the study of argumentation. Studies in Logic, Grammar and Rhetoric 36: 41-58.

Stampe, D.W. 1967. On the acoustic behavior of rational animals. Madison: University of Wisconsin.

Stampe, D.W. 1975. Meaning and truth in the theory of speech acts. In Speech Acts, eds. P. Cole and J.L. Morgan, 1-39. New York: Academic Press.

Strawson, P.F. 1964. Intention and convention in speech acts. Philosophical Review 73(4): 439-460.

Strawson, P.F. 1974. Freedom and resentment and other essays. London: Methuen.

Sweeny, J. 2017, 29 Apr. Not covered under the First Amendment: The ACLU is wrong about Trump and incitement to violence. Salon. Retrieved from www.salon.com.

Wilentz, S. 2009, July 15. Who Lincoln was and was not: The images and illusions of this momentous bicentenntial year. The New Republic, 24-47. 